\title{
Manejo terapéutico inicial de las heridas por arma de fuego en el territorio maxilofacial
}

\section{Initial therapeutic management of firearm wounds in the maxillofacial area}

\author{
L. Ruiz Laza , J. Herrera Cobos², J.M. Díaz Fernández³, J.D. González Padilla', R. Belmonte Caro4, \\ A. García-Perla García ${ }^{4}$ J.L. Gutiérrez Pérez
}

\begin{abstract}
Resumen: Introducción. Las heridas por armas de fuego son poco frecuentes en nuestro medio, de ahí que la experiencia en el manejo de las mismas sea limitada. En este artículo mostramos la experiencia de nuestro Servicio en el tratamiento de estas lesiones y realizamos una revisión del tema para intentar protocolizar la actuación inicial ante este tipo de pacientes. Material y Método. Presentamos seis casos tratados en nuestro Servicio durante el año 2002. Estudiamos las características demográficas, etiología, patrón de lesiones y tratamiento recibido. Resultados. Cinco hombres y una mujer presentaron heridas por arma de fuego durante este período, con una edad media de 38 años (Rango 13-74). La etiología más frecuente fue la agresión, seguido del intento de autolisis. Sólo un paciente requirió estabilización urgente de vía aérea mediante traqueotomía. No existieron complicaciones postoperatorias y sólo un enfermo requirió intervenciones secundarias por secuelas. Discusión. El aspecto más controvertido en el tratamiento de estas lesiones es el manejo quirúrgico de pacientes con lesiones extensas de la cara que involucran partes blandas y hueso, ya que pueden tratarse con técnicas reconstructivas complejas en el primer acto operatorio o, por el contrario, esta reconstrucción se puede realizar de forma diferida tras una primera fase de tratamiento quirúrgico de desbridamiento, estabilización de fracturas y cierre de partes blandas con técnicas simples. Pensamos que la elección del tipo de tratamiento debe ser individualizada en cada caso, aunque solemos optar por una reconstrucción diferida de los defectos tan pronto como sea posible.
\end{abstract}

Palabras clave: Armas de fuego; Traumatismos faciales; Reconstrucción.
Aceptado: 06.10 .2006

\footnotetext{
1 F.E.A Cirugía Oral y Maxilofacial. Hospital Infanta Cristina. Badajoz.

2 Especialista en Cirugía Plástica, Reparadora y Estética.

Médico Residente de Cirugía Oral y Maxilofacial. Hospital Gregorio Marañón. Madrid.

3 F.E.

4 Cirugía Oral y Maxilofacial. Hospital General Universitario de Valencia.

Servicio de cirugía oral y maxilofacial. Hospitales Universitarios Virgen del Rocío. Sevilla. Madrid.

Correspondencia:

Luis Ruiz Laza

Av. de Elvas s/n - 06080 Badajoz. España

e-mail: Iruizlaza@hotmail.com
}

\begin{abstract}
Introduction. The firearm injuries are not very common in our country, and the experience in its management is limited. In this review we show the experience of our Service in this wounds and review the literature to systematize the initial management of the firearm injuries in maxillofacial region. Material and Method. We present six patients treated in our Service in 2002. We study the demographics characteristic, aetiology, lesions patterns and treatment. Results. Five male and a female were treated of firearm lesions during this period, with a mean age of 38 years (range 13-74). Most frequent aetiology was the aggression. Only one patient required emergency airway control with tracheotomy. No complications were noted after primary surgical treatment and only one patient needed secondary surgical intervention. Discussion. There are controversy in definitive surgical treatment in patients with high-energy lesions in maxillofacial region, because the literature describe two forms of management. The first way is the primary reconstruction with microvascular techniques, or secondary reconstruction after desbridement, stabilization of existing bone and primary closure of soft tissue. We think that the choice of treatment must be individualized, and we choose the secondary reconstruction as early as possible after primary stabilization of wounds.
\end{abstract}

Key words: Firearm; Maxillofacial injuries; Reconstruction. 


\section{Introducción}

Los traumatismos faciales provocados por armas de fuego en nuestro medio son raros, probablemente debido a la legislación sobre posesión de armas de fuego vigente en nuestro país. Esta falta de experiencia unido a las características especiales de estas lesiones, que requieren en muchas ocasiones el empleo de técnicas reconstructivas microquirúrgicas para su tratamiento definitivo, hacen que este tipo de pacientes constituyan un reto para el cirujano oral y maxilofacial.

La severidad de las lesiones por arma de fuego depende de dos variables fundamentalmente. La primera variable se debe al calibre del proyectil y a la velocidad con la que se dispara, que son dependientes del arma utilizada. La segunda variable relacionada es la distancia a la que se realiza el disparo, que fue clasificada por Sherman y Parrish en tres tipos: tipo I, aquellos realizados más allá de 6,6 metros; tipo II entre 6,6 y 2,74 metros; y tipo III a menos de 2,74 metros. ${ }^{1}$ Como veremos posteriormente, estas lesiones se pueden clasificar de forma básica en dos grandes grupos: las de alto y las de bajo grado de energía. ${ }^{2}$ Además, hay que tener en cuenta la región donde se produce, ya que las lesiones en el territorio maxilofacial pueden tener importantes secuelas estéticas y funcionales, o lo que es más grave, provocar la muerte del paciente.

\section{Manejo inicial del lesionado}

El paciente con lesiones por arma de fuego debe ser evaluado inicialmente siguiendo las reglas de reanimación básica de cualquier politraumatizado (Regla $A B C$ ). ${ }^{3}$

El primer paso lo constituye la estabilización de la vía aérea. Son muchos los parámetros que debemos valorar para determinar la necesidad o no de la estabilización de la vía aérea, ya que en diversos estudios publicados sólo necesitan estabilización urgente de la vía aérea un porcentaje que varía entre el 25 y el $35 \%$ de estos pacientes. ${ }^{4}$ El factor más importante en este aspecto es la gravedad y extensión de las lesiones provocadas, siendo las indicaciones más claras para estabilizar de forma urgente aquellas que involucran el tercio inferior de la cara y suelo de la boca. ${ }^{5}$ Sin embargo, aquellos pacientes con lesiones de menor importancia deben ser vigilados de forma continuada las primeras horas de su ingreso por la posibilidad de formación de hematomas en la vía aérea. En cuanto a la forma de estabilización de la vía aérea, ésta debe estar en función del patrón y localización de las lesiones que nos encontremos, siendo preferible la intubación nasotraqueal cuando no existan contraindicaciones, tales como la afectación del tercio medio. ${ }^{4}$ Una vez estabilizada la vía aérea debemos mantener la correcta ventilación del paciente con las medidas oportunas (Paso B).

El paso $C$ de la reanimación básica es la estabilización hemodinámica. En estos pacientes podemos encontrarnos con un sangrado activo por las lesiones, o lo que es más grave con alguna lesión vascular importante. En el primer caso, el sangrado suele revertir con medidas compresivas en la zona, tales como taponamientos nasales anteriores y posteriores, taponamientos orofaríngeos, etc. En el segundo caso estaría indicado la realización de una arteriografía diagnóstica y realización de embolización selectiva del vaso lesionado ${ }^{6}$ o en su defecto la exploración quirúrgica urgente y hemostasia del vaso afectado.

\section{Introduction}

Facial trauma produced through firearms is rare in our country, probably due to current legislation on firearm possession. This lack of experience together with the particular characteristics of these injuries, which on many occasions require the use of microsurgical reconstruction techniques for their definitive treatment, make this type of patient a challenge for the oral and maxillofacial surgeon.

The severity of firearm injuries depends fundamentally on two variables. The first variable depends on the caliber of the projectile and the speed at which it is fired, and this depends on the firearm employed. The second related variable is the distance at which it is fired. This was classified by Sherman and Parrish into three types: Type I, those carried out at a distance of more than 6.6 meters; Type II between 6.6 and 2.74 meters; and Type III from less than 2.74 meters. ${ }^{1}$ As we shall see later, these lesions can be classified in a basic form into two large groups: high energy and low energy. ${ }^{2}$ In addition, one has to take into account where these are produced, as injuries in the maxillofacial region can have important aesthetic and functional sequelae, or what is more serious, lead to the death of the patient.

\section{Initial management of the injured}

The patient with firearm injuries should be evaluated initially according to the rules of basic reanimation for any polytraumatized patient (ABC Rule). ${ }^{3}$ The first step consists in stabilizing the airways. There are many parameters that have to be evaluated in order to determine the need or not for stabilizing the airways, as according to various publications only 25 to $35 \%$ of these patients require emergency airway stabilization. ${ }^{4}$ The most important factor in this sense is the seriousness and extension of the injuries produced, and urgent stabilization of the injuries affecting the lower third of the face and floor of the mouth are clearly indicated. ${ }^{5}$ However, those patients with injuries that are less important should be monitored continuously for the first few hours after being admitted because of the possibility of hematoma formation in the airways. With regard to airway stabilization, this should be carried out according to the pattern and location of the injuries encountered. Nasothracheal intubation is preferable when there are no contraindications such as involvement of the middle third of the face. ${ }^{4}$ Once the airways have been stabilized we should maintain the correct ventilation of the patient with the appropriate measures (Step B).

Step $C$ of basic reanimation is hemodynamic stabilization. In these patients we may find active bleeding because of the injuries, or what is more serious, vascular injury of considerable importance. In the first case, the bleeding tends to revert with the use of compression in the area, such as anterior and posterior nasal packing, oropharyngeal packing, etc. In the second case, carrying out a diagnostic arteriography and selective embolization of the injured vessel is indi- 
Una vez controlados los aspectos más importantes del paciente pasamos a la valoración integral del mismo, centrándonos especialmente en lesiones intracraneales y oculares, bastante frecuentes en este tipo de pacientes, en torno al $15 \%$ las cerebrales y $30 \%$ las oculares, que deben ser manejadas por los respectivos especialistas. ${ }^{7}$ Además, debemos realizar profilaxis antitetánica y antibiótica de amplio espectro en todos los pacientes. ${ }^{1}$

\section{Valoración específica de las lesiones}

Una vez estabilizado el paciente, pasamos a realizar una valoración integral de las lesiones provocadas por el arma de fuego en el territorio maxilofacial. Para ello, procedemos a limpiar las lesiones con suero fisiológico abundante y a retirar cualquier cuerpo extraño que encontremos. En esta exploración debemos centrarnos en primer lugar en las partes blandas, donde reflejamos el área de lesión, los tejidos que se han perdido y aquellos que están dañados con su consiguiente grado de viabilidad. En este punto es importante señalar si existen o no lesiones provocadas por la salida del proyectil, ya que la falta de estas lesiones nos debe hacer sospechar la existencia del mismo alojado en alguna porción del territorio maxilofacial. Posteriormente exploramos el esqueleto óseo siguiendo la misma sistemática, es decir, reflejar el hueso perdido y aquel que está lesionado y su viabilidad. ${ }^{2}$

Todo ello debe ser complementado con pruebas radiológicas específicas, siendo de gran utilidad radiografías simples de la cara en dos proyecciones, una ortopantomografía y una proyección de Waters. Además, cuando se afecta el tercio medio facial o se sospecha lesión ocular o neurológica, está indicado la realización de una Tomografía Computerizada, debiendo realizarse distintos cortes para valorar todas las estructuras faciales, ${ }^{5}$ siendo de especial utilidad las reconstrucciones en tres dimensiones para la planificación del tratamiento. ${ }^{8}$ Pueden ser útiles otras pruebas diagnósticas, como la realización de una arteriografía, que además de estar especialmente indicada ante un sangrado activo de las lesiones que no remiten con medidas habituales, como ya hemos referido, se debe realizar ante sospecha de cuerpo extraño cerca del paquete vascular principal, y en general ante heridas penetrantes en la región cervical y base de cráneo. ${ }^{5}$ En casos de heridas penetrantes o perforantes cervicales puede estar indicado la realización de una endoscopia para valoración del esófago, buscando posibles lesiones a ese nivel. ${ }^{3}$

\section{Tratamiento quirúrgico}

Una vez que hemos realizado todos los pasos anteriores, debemos estar capacitados para clasificar las lesiones provocadas por cated, ${ }^{6}$ or if not urgent surgical examination and hemostasia of the affected vessel.

Once the more important aspects of the patient have been controlled we can then proceed with their assessment as a whole, concentrating especially on the intracranial and ocular lesions that are quite common in these types of patients, with around $15 \%$ relating to the brain, 30\% to the eye, which should be managed by the respective specialists. ${ }^{7}$ In addition, wide spectrum antitetanus and antibiotic prophylaxis should be carried out in all patients. $^{1}$

Specific injury assessment Once the patient has been stabilized, a thorough evaluation should be carried out of the injuries produced by the firearm in the maxillofacial area. For this we proceed to clean the lesion using a generous amount of sterile saline and any strange bodies that are found are removed. In this examination we should concentrate firstly on soft tissues. The area of the lesion is examined, and the tissues that have been lost are noted together with the degree of viability of those that have been damaged. At this point it is important to observe if there are any injuries as a result of the exit of the projectile, as if there is no injury of this type we should assume that the missile is lodged in a different part of the maxillofacial area. We will then examine the skeleton following the same system, that is, lost bone will be noted together with the viability of damaged bone. ${ }^{2}$

All this should be carried out together with specific radiologic tests. This should include plain film radiography of two vi ews of the face which is of great use, an orthopantomography and a Water's view. In addition, when the midthird of the face is affected, or an ocular or neurological lesion is suspected, carrying out a Computerized Tomography is indicated, with different views being necessary in order to evaluate all facial structures. ${ }^{5}$ Reconstructions in $3 D$ in order to plan treatment are particularly useful. ${ }^{8}$ Other diagnostic tests can be useful, such as an arteriography. This is particularly indicated when there is active bleeding that does not cease with the normal steps mentioned previously, and one should be carried out if a strange body is suspected near the main vascular bundle, and in general when there are penetrating injuries in the area of the neck and skull base. ${ }^{5}$ When there are penetrating injuries or perforating neck 
el arma de fuego, y que va a servir de guía para el manejo definitivo de estos traumatismos. Existen múltiples clasificaciones, aunque nosotros nos basamos en dos de ellas: la primera distingue tres tipos en función del patrón de entrada y salida del proyectil, encontrándonos lesiones penetrantes (sólo orificio de entrada); lesiones perforantes (orificio de entrada y salida) que suelen estar provocadas por armas de pequeño calibre y larga distancia; y lesiones avulsivas provocadas por armas a una distancia muy corta del paciente con gran pérdida de sustancia. ${ }^{3}$ Otros autores simplifican esta clasificación en lesiones de bajo y alto grado de energía, en relación a la pérdida de sustancia y lesiones provocadas en la cara. ${ }^{2}$

Las lesiones de bajo grado de energía son las más frecuentes; estas heridas son provocadas por armas de pequeño calibre a una distancia no cercana al paciente. Este grupo de lesiones presentan un patrón similar al de una traumatismo facial con herida abierta; el tejido blando presenta mínima pérdida de sustancia y escasa necrosis perilesional; las lesiones óseas asociadas son muy variables en función de la región afecta, no apreciándose avulsión de hueso pero pudiendo dar lugar a fracturas conminutas difíciles de tratar. En principio, este tipo de lesiones se deben tratar de forma similar a cualquier otro traumatizado facial, teniendo en cuenta que el paciente puede tener el proyectil en su interior y debe ser valorada su extracción. El pronóstico de este patrón de lesiones es bueno debido a la buena cobertura de tejidos blandos que existe; sin embargo, se han descrito complicaciones en pacientes con heridas en el tercio inferior facial que dan lugar a fracturas mandibulares conminutas y daño en la mucosa oral que compromete la vascularización de estos fragmentos; en estos casos debemos reponer los fragmentos óseos y reparar los tejidos blandos, vigilando postoperatoriamente la presencia de infección localizada, fístulas resistentes a tratamiento adecuado o retardo en la consolidación de la fractura, donde debemos plantearnos el desbridamiento precoz de la zona y posterior reconstrucción del defec-

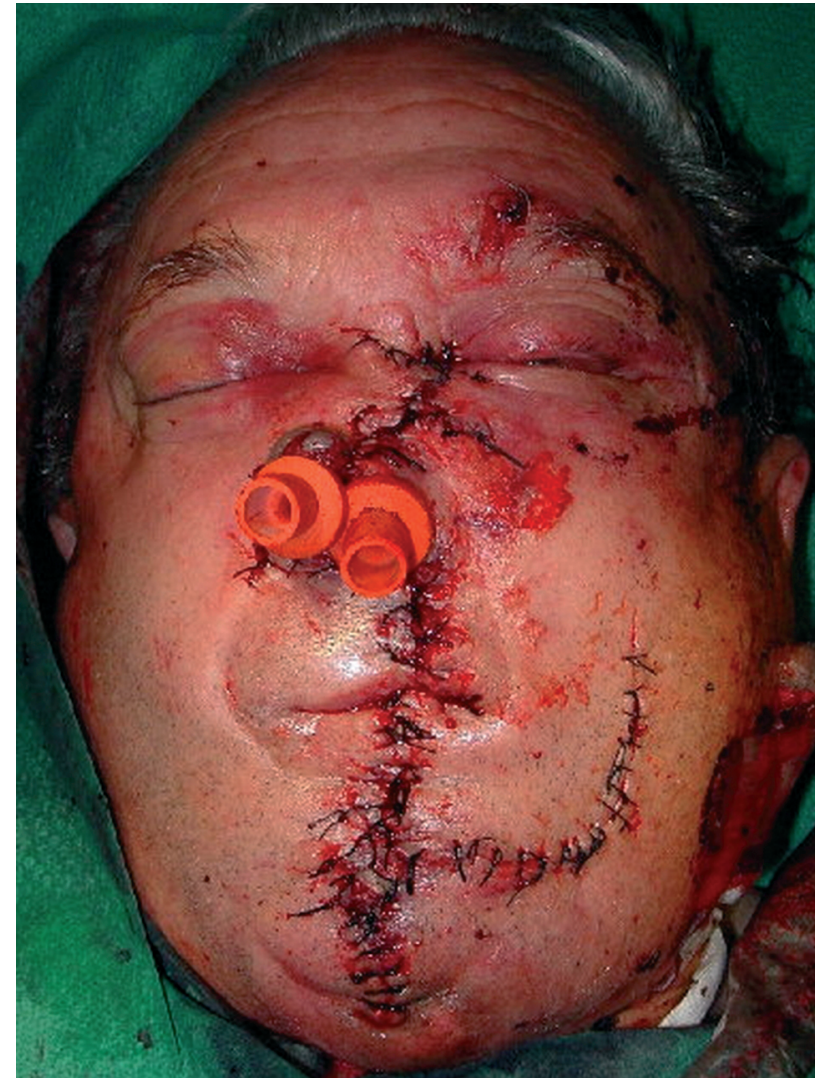

Figura 2. Aspecto del paciente 1 tras tratamiento quirúrgico primario.

Figure 2. View of Patient 1 following primary surgical treatment.

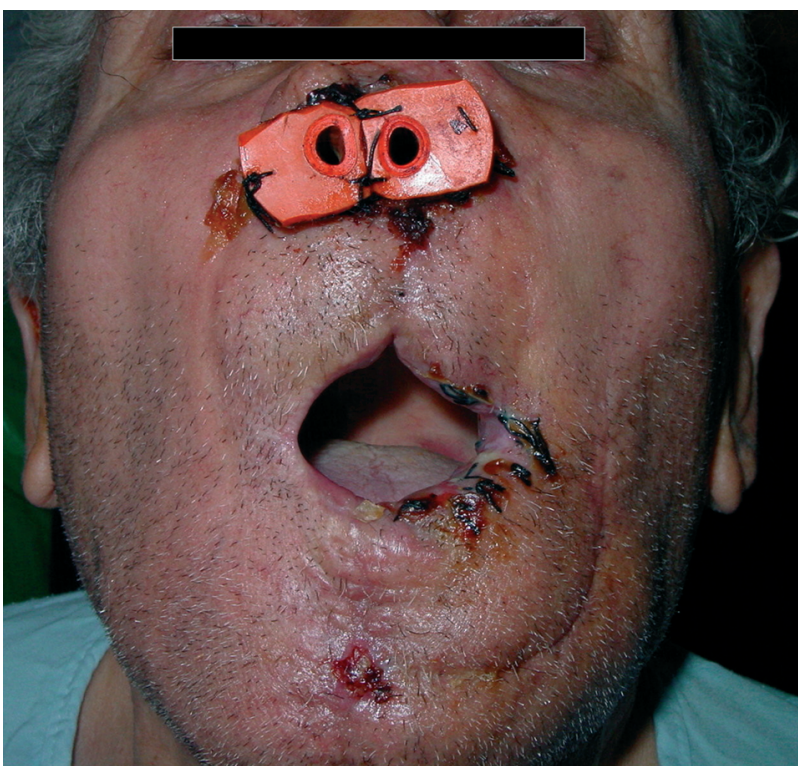

Figura 3. Paciente 1 al mes de intervención primaria y tras comisuroplastia unilateral.

Figure 3. Patient 1 a month after primary surgery and unilateral commissuroplasty.

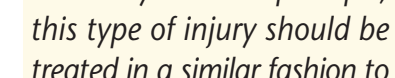

that of any other patient with facial trauma, bearing in mind that the patient can have the projectile within him and its 
to, que se realiza unas ocho semanas después de que confirmemos la integridad y salud de los tejidos blandos de la zona..$^{2,9}$

Las heridas por arma de fuego de alta energía son aquellas provocadas por grandes proyectiles o por armas colocadas a escasa distancia del enfermo. Son lesiones bastante complejas; donde se aprecia gran pérdida de tejidos blandos y tejidos circundantes con tendencia a la isquemia y necrosis posterior, acompañadas además de lesión ósea variable con pérdida de hueso y fracturas complejas. ${ }^{2}$ La prioridad de tratamiento en este tipo de lesionados es la reposición de partes blandas para tener una buena cobertura de las lesiones óseas y sus posibles reconstrucciones con injertos o colgajos microvascularizados. Se asume que el manejo quirúrgico de estas lesiones está divido en tres fases: la primera de desbridamiento, estabilización de las fracturas y cierre primario con técnicas simples; la segunda, de reconstrucción ósea con adecuada cobertura de partes blandas mediante injertos o preferiblemente colgajos microvascularizados; y la tercera y última, donde se realiza una corrección de deformidades residuales y se prepara al paciente para una rehabilitación oral lo más completa posible. ${ }^{10}$ La controversia radica en si estas fases se realizan en un solo tiempo quirúrgico de forma primaria o en varias intervenciones, ya que mientras la mayoría de los autores recomiendan una reconstrucción inmediata de todas las lesiones para mejorar los resultados estéticos y funcionales mediante técnicas reconstructivas complejas con colgajos microvascularizados, 1,7,10 otros recomiendan una actitud más conservadora realizando el tratamiento en varias fases en aquellos casos complejos donde existe una severa afectación de tejidos blandos y hueso que puedan hacer fracasar la reconstrucción primaria. ${ }^{2,3}$ La elección de la actitud terapéutica viene en función de varios aspectos, tales como experiencia y disponibilidad de medios, extensión de la lesión y estado de salud

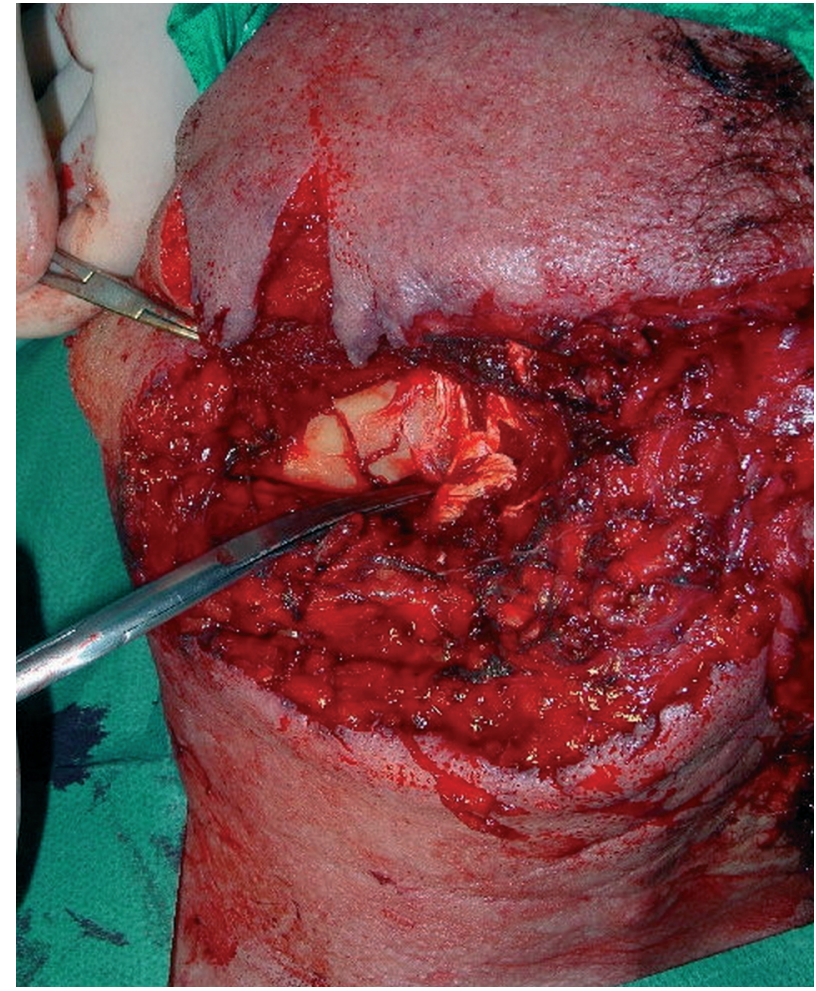

Figura 4. Detalle de lesiones en región lateral del paciente 2. Figure 4. Detail of the injuries in the lateral region of Patient 2.
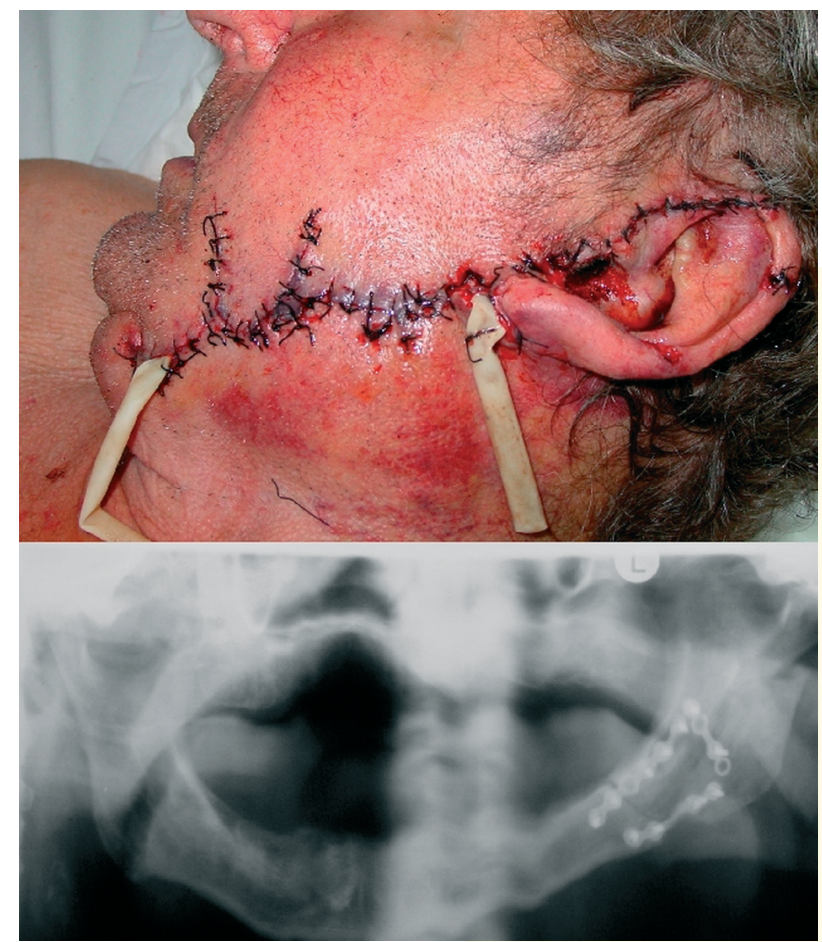

Figura 5. Visión lateral del paciente 2 a los 2 días de tratamiento y detalle de la OPG tras reducción anatómica de la fractura de ángulo mandibular.

Figure 5. Lateral view of Patient 2 after two days of treatment and OPG detail after anatomic reduction of the mandibular angle fracture. extraction should be assessed. The prognosis for injuries with this pattern is good, due to there being good existing soft tissue coverage. However, complications have been described in patients with wounds in the lower third of the face leading to comminuted mandibular fractures and damage to the oral mucosa that compromises the vascularization of these fragments. In these cases bone fragments should be replaced and soft tissue repaired. The presence of localized infection should monitored during the post-operative period together with any fistulas resistant to adequate treatment. If there is a delay in fracture consolidation we should consider early debridement of the area and the posterior reconstruction of the defect. This should be carried out eight weeks later, once the integrity and health of the soft tissue in the area has been confirmed.2,9 High energy injuries from firearms are those from large projectiles or high energy firearms at a short distance. These injuries are quite complex; large areas of soft tissue and surrounding tissue is lost, and there is a tendency for ischemia to develop and for later necrosis, accompanied in addition by variable bone injuries with bone loss and complex fractures. ${ }^{2}$ When treating this type of injury, priority is given to soft tissue replacement in order for there to be good coverage of bone injuries and possible reconstruction with grafts and microvascular flaps. It is assumed that the surgical management of these lesions is divided into three phases: the first is debridement, stabilization of fractures and primary closure with simple techniques; the second, bone reconstruction with adequate soft tissue cover by means of grafts or preferably microvas- 
general del enfermo. ${ }^{10}$ De todas maneras, todos los autores coinciden en que la reconstrucción secundaria debe ser realizada lo más precozmente posible una vez que tengamos los tejidos blandos en buen estado.

\section{Material y método}

Presentamos seis casos de pacientes con heridas por arma de fuego tratados en el Servicio de Cirugía Oral y Maxilofacial de los Hospitales Universitarios Virgen del Rocío (Sevilla, España) durante el año 2002. En ellos estudiamos las características demográficas, la etiología, el patrón de lesiones, el tratamiento recibido y su resultado estético y funcional.

\section{Resultados}

Los resultados obtenidos se resumen en la tabla 1. Fueron tratados en nuestro Servicio cinco hombres y una mujer con una edad media de 38 años (Rango 13-74). Dos de los pacientes fueron intento de autolisis con rifle de caza colocado sobre el mentón, provocando lesiones de alta energía. Los cuatro casos restantes fueron heridas por armas de pequeño calibre a una distancia mayor de 2,74 metros que provocaron lesiones de baja energía, tres de ellos por agresión y otro de forma accidental. Sólo uno de ellos requirió estabilización urgente de la vía aérea mediante traqueostomía (paciente 1) debido a la gravedad de lesiones centrofaciales que provocó el arma con afectación del tercio inferior facial. Ninguno de los pacientes requirió medidas de estabilización hemodinámica por sangrado activo de las lesiones; sólo un paciente (paciente 3 ) requirió la realización de una arteriografía por sospecha de lesión de los grandes vasos cervicales debido al orificio de entrada y dirección del proyectil. Sólo en el paciente 1 se realizó interconsulta con Oftalmología por posibilidad de lesiones oculares.

En los pacientes con lesiones de alta energía se optó por realizar tratamiento por etapas debido a la edad y complejidad de las

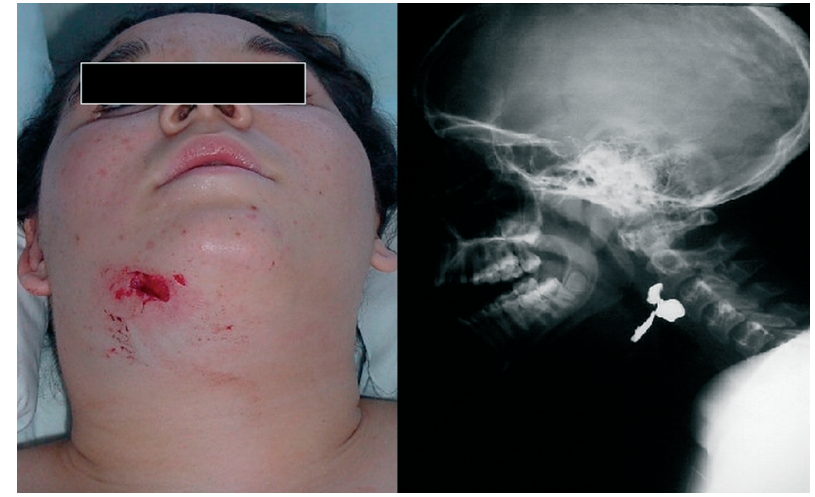

Figura 6. Orificio entrada proyectil en paciente 3 , se aprecia cuerpo extraño en estrecha relación con el glomus carotídeo derecho. Figure 6. Entry orifice of the projectile in Patient 3 and detail of the lateral radiograph of the skull.

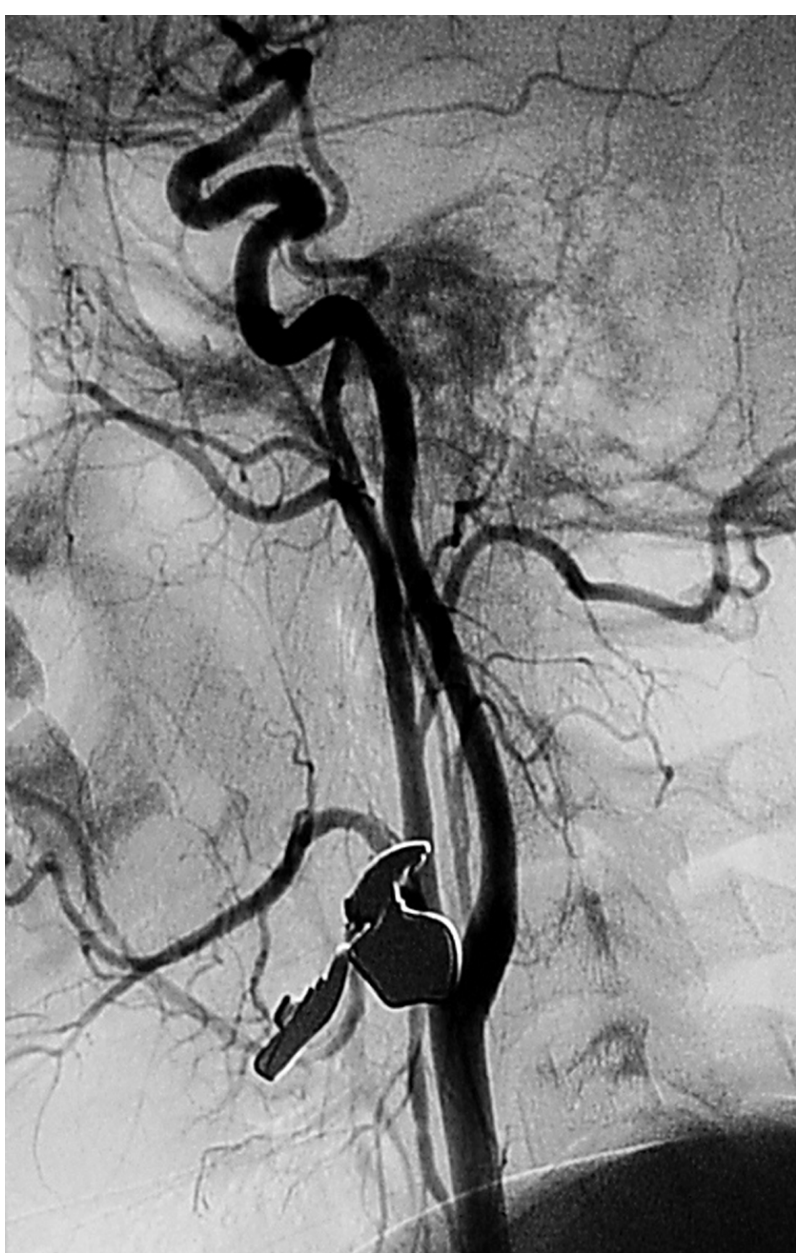

Figura 7. Arteriografía de la paciente 3, se aprecia cuerpo extraño en estrecha relación con el glomus carotídeo derecho.

Figure 7. Arteriography of Patient 3 showing strange body in close contact with right carotid glomus. cular flaps; and the third and last, when there is a correction of residual deformities and the patient is prepared for oral rehabilitation that is as complete as possible. ${ }^{10}$ The controversy lies in if these phases should be carried out in a single surgical act in a primary fashion, or as various interventions. While most authors recommend immediate reconstruction of all lesions in order to improve aesthetic and functional results by means of complex reconstruction techniques with microvascularized flaps, 1,7,10 others recommend a more conservative attitude and that treatment be carried out in various stages for those complex cases where soft tissue and bone is seriously affected, and where primary reconstruction may fail.2,3 Choosing a therapeutic approach depends on various aspects such as experience, availability of resources, wound extension and the general health of the patient. ${ }^{10}$ In any event, all authors agree that secondary reconstruction should be carried out as quickly as possible once the soft tissue is in good condition.

\section{Material and Methods}

We present six cases of patients with firearm wounds that were treated in our department of Oral and Maxillofacial Surgery in the Hospitales Universitarios Virgen del Rocío (Sevilla, España) during 2002. The demographic characteristics, etiology, pattern of injuries, treatment received and aesthetic and functional results are examined.

\section{Results}

The results obtained are summed up in table 1. Five men and one woman were treated by our department. Mean age 
Ilin! |

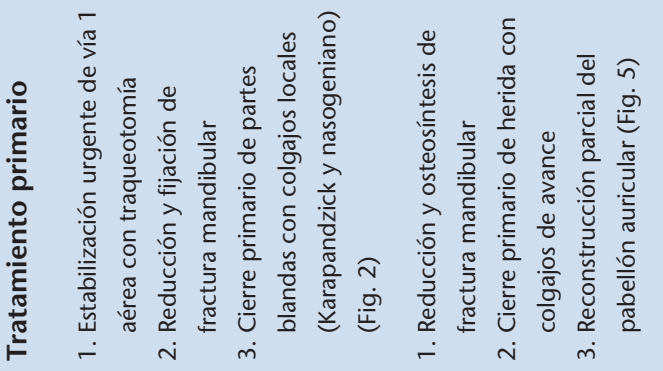

운

$\stackrel{\circ}{2}$

ㅇ
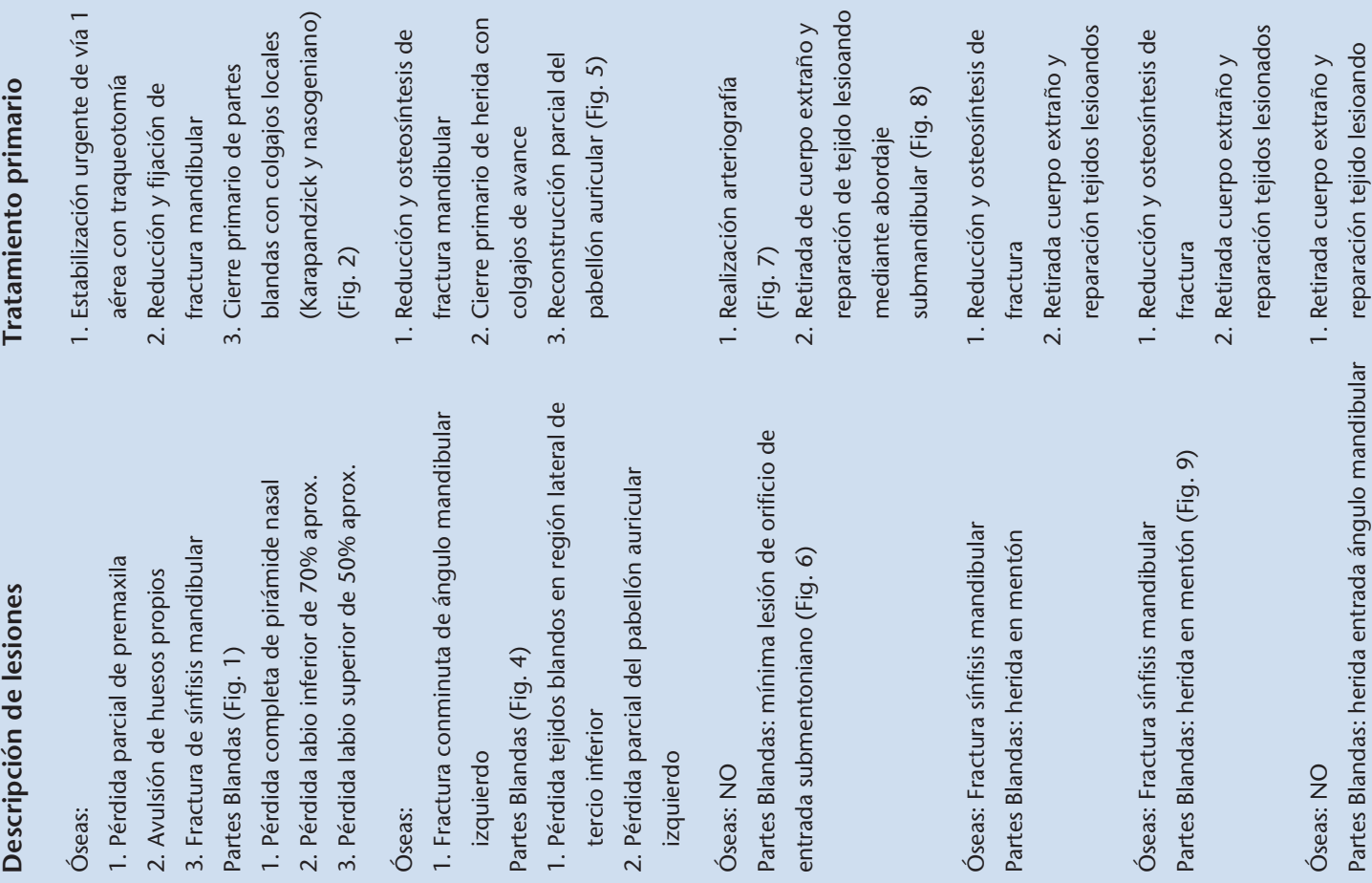

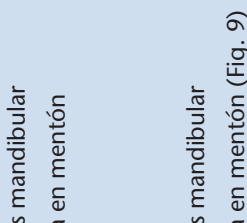

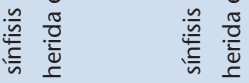

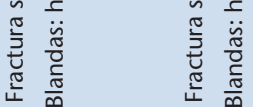

总商产

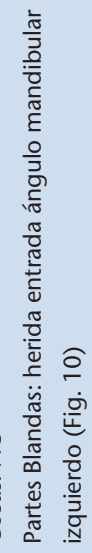
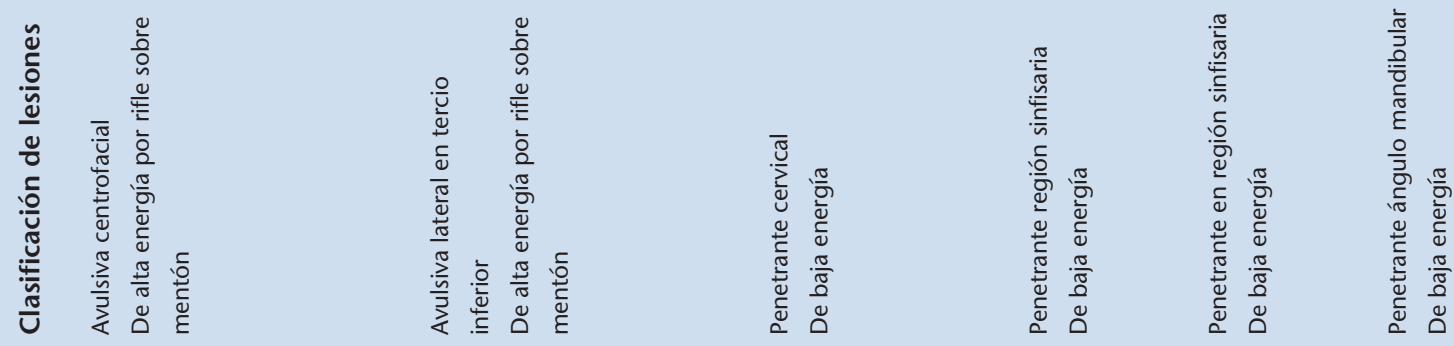

军

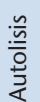

$\frac{\sqrt{0}}{\frac{2}{\bar{n}}}$

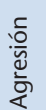

高

$\frac{\sqrt{0}}{\frac{0}{0}}$

ঙำ I

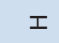

超

N

$\stackrel{m}{n}$

$\hat{N}$

$\approx$

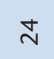



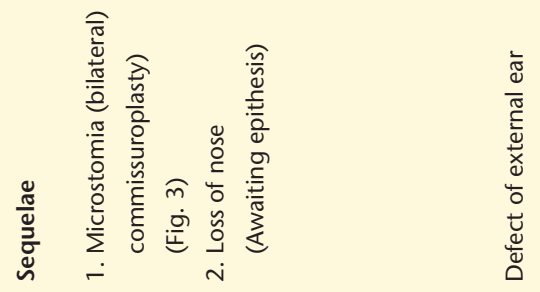

岁
○

$\begin{array}{ll}\text { 山ू } & \text { Uू } \\ \text { Ò } & \text { Oे }\end{array}$

U
O
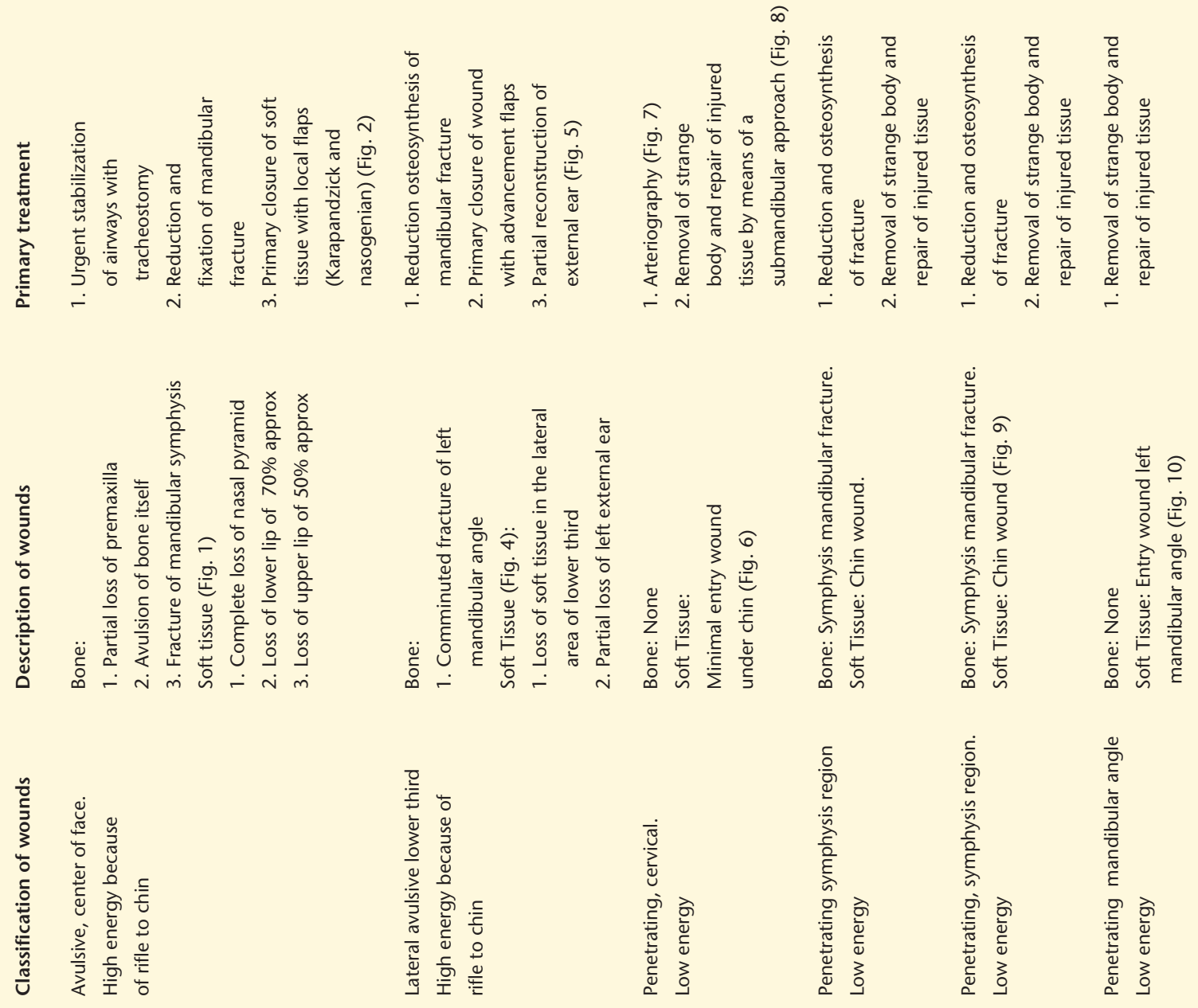

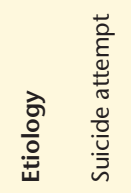

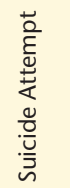

๖ $\Sigma$

$\frac{d}{2}$

$\frac{-}{\sqrt{0}}$

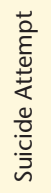

$\Sigma$

$\stackrel{N}{N}$

$\frac{\substack{\frac{1}{2} \\ \frac{0}{\pi}}}{2}$ $\frac{}{\circ}$
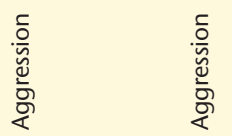

$\frac{\sqrt{5}}{\frac{\pi}{0}}$

$\stackrel{m}{r}$

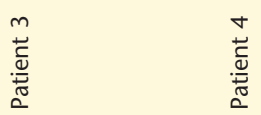

ฟิ

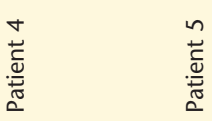

$\stackrel{\sim}{\sim}$

$\begin{array}{ll}n & 0 \\ \frac{\pi}{\pi} & \frac{\pi}{\pi} \\ \frac{\pi}{0} & \frac{\pi}{0}\end{array}$ 
lesiones (Paciente 1); o porque el tratamiento primario tuvo resultados satisfactorios (Paciente 2). En cuanto al resto de los pacientes con lesiones de baja energía se trataron como cualquier traumatismo de otra etiología; sin presentar complicaciones destacables intraoperatoriamente y con resultados satisfactorios.

La estancia media postoperatoria fue de 14 días (rango 4-36 días). No tuvimos ningún caso de infección postoperatoria, y sólo el paciente 1 ha requerido reintervención por microstomía, realizándose una comisuroplastia para que el paciente pudiera colocarse una prótesis total removible. Este paciente está pendiente de reconstrucción nasal, respecto a la que hemos optado por el uso de una epítesis implantosoportada, pendiente de realización.

\section{Discusión}

Las características demográficas que encontramos en nuestro medio siguen básicamente dos patrones: el primero lo constituyen pacientes de edad avanza$\mathrm{da}$, en medio rural, que por intento de autolisis se provocan lesiones de alta energía al colocar el arma apoyada sobre el mentón; el segundo patrón está formado por pacientes más jóvenes en medio urbano que sufren lesiones de baja energía por armas de menor calibre y producidas tras agresión, y que están aumentando paulatinamente en nuestras ciudades. Estos patrones no son comparables con otros estudios publicados debidos a las diferencias socioculturales de nuestro país.

En nuestra experiencia sólo un paciente requirió estabilización urgente de vía aérea (16,6\%), coincidiendo con otras series, debido a la complejidad de las lesiones faciales que presentaba. ${ }^{4,5}$ Ninguno de ellos presentó sangrado activo por las lesiones provocadas por el arma, probablemente debido al efecto térmico que provocan las armas de fuego sobre las partes blandas, y ninguno presentó lesiones oculares ni neurológicas asociadas por los patrones de las heridas sufridas en nuestros pacientes.

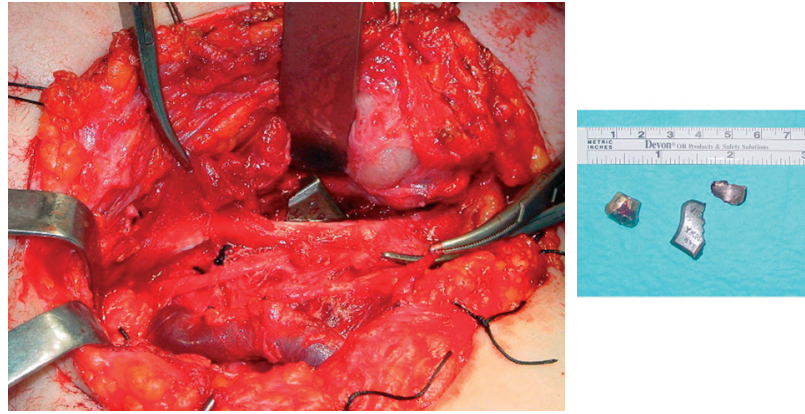

Figura 8. Detalle de intervención para extracción del cuerpo extraño vía cervical submandibular y cuerpo extraño extraído.

Figure 8. View showing intervention detail in order to extract the strange body via submandibular neck area and strange body once extracted.

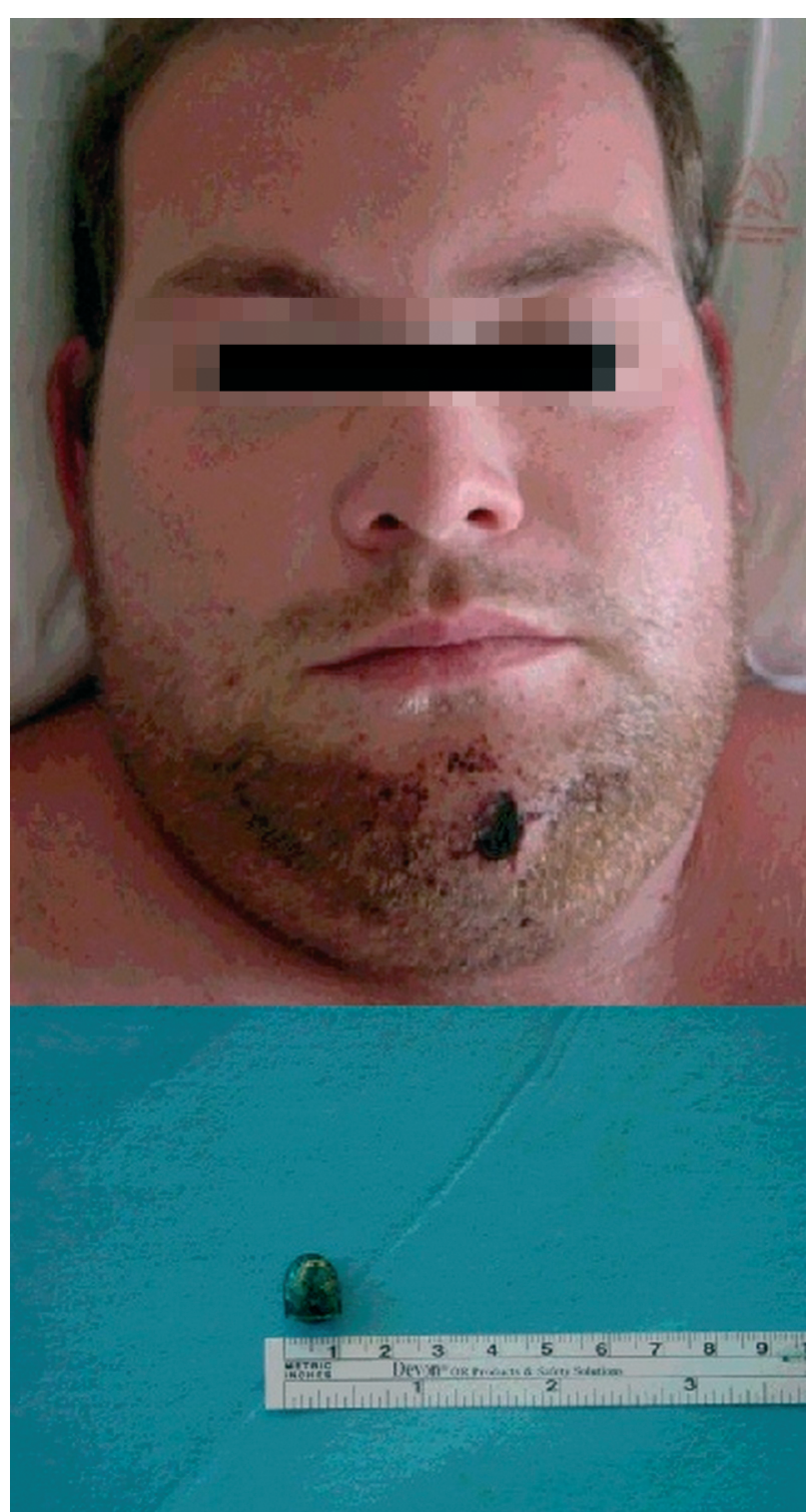

Figura 9. Visión paciente 5 con herida en sínfisis. Detalle del proyectil.

Figure 9. VView of Patient 5 with symphysis wound. Detail of projectile. was 38 (range 13-74). Two of the patients were suicide attempts with hunting rifles placed to the chin that produced high energy injuries. The four remaining cases were small caliber injuries from a distance of over 2.74 meters that caused low energy injuries, three of these were because of aggression, and the other was accidental. Only one patient required urgent stabilization of the airways by means of a tracheostomy (Patient 1) due to the severity of the injuries to the center of the face from the weapon and that affected the lower third of the face. None of the patients required hemodynamic stabilization due to active bleeding from injuries. Only one patient (Patient 3) required an arteriography as injury to the large vessels in the neck was suspected, as a result of the entry orifice and direction of the projectile. There was interdepartmental consultation with Ophthalmology only with Patient 1 as there was a possibility of ocular injury.

Treatment in stages was opted for with the patients with high energy injuries due to the age of these patients and the complexity of the injuries (Patient 1); or because primary treatment had satisfactory results (Patient 2). With regard to the remaining patients with low-energy injuries, these were treated as any other trauma of another etiology. There were no intraoperative complications worth mentioning, and the results were satisfactory.

The postoperative stay was 14 days (range 4-36 days). There were no cases of postoperative infection, and only Patient 1 required reintervention because of microstomia. A commissuroplasty was carried out so that the patient could 
El tratamiento realizado a todos ellos fue la estabilización de fracturas y reparación de partes blandas asociadas mediante técnicas simples. En este sentido pensamos que es el tratamiento de elección en la mayoría de los pacientes, dejando para un segundo tiempo reconstrucciones microquirúrgicas complejas una vez que tenemos bien delimitado los defectos y las necesidades reconstructivas de cada paciente. Pensamos, al igual que otros autores, que esta reconstrucción secundaria se debe realizar lo más

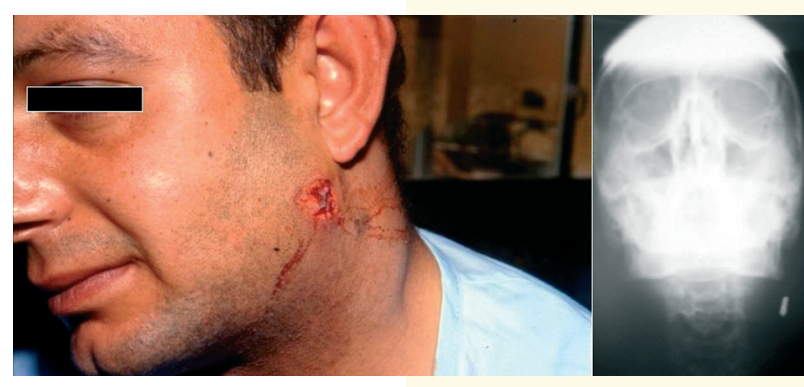

Figura 10. Visión del paciente 6 con orificio en región cervical. Detalle de radiografía.

Figure 10. Vision of Patient 6 with orifice in the region of neck. Detail of radiograph. precozmente posible para obtener los mejores resultados estéticos y funcionales. ${ }^{2,3}$

\section{Conclusiones}

Las heridas por arma de fuego son raras en nuestro medio y la experiencia en el tratamiento de las mismas es limitada. Es importante el manejo inicial de estos pacientes de forma integral como en cualquier otro politraumatizado, y el tratamiento definitivo de las lesiones debe estar racionalizado en función de las características del enfermo y de la experiencia del equipo que lo trata.

\section{Bibliografía}

1. Alper M, Totan S, Çankayali R, Songür E. Gunshot wounds of the face in attempted suicide patients. J Oral Maxillofac Surg 1998;56:930-4.

2. Clark N, Birely B, Manson PN, Slezak S, Vander Kolk G, Robertson B, Crawley W. High-energy ballistic and avulsive facial injuries: Classification, patterns, and an algorithm for primary reconstruction. Plast Reconstr Surg 1996;98:583-601.

3. Cunningham LL, Haug RH, Ford J. Firearm injuries to the maxillofacial region: an overview of current thoughts regarding demographics, pathophysiology, and management. J Oral Maxillofac Surg 2003;61:932-42.

4. Demetriades D, Chahwan S, Gomez H, Falabella A, Velmahos G, Yamashita D. Initial evaluation and management of gunshot wounds to the face. I Trauma 1998;45:39-41.

5. Chen Ay, Stewart MG, Raup G. Penetrating injuries of the face. Otolaryngol Head Neck Surg 1996;115:464-70.

6. Byone RP, Kerwin AJ, Parker HH 3rd, Nottingham JM, Bell RM, Yo MJ, Close TC, Hudson ER, Sheridan DJ, Wade MD. Maxillofacial injuries and life-threatening hemorrhage: treatment with transcatheter arterial embolization. / Trauma 2003;55:74-9.

7. Hollier L, Grantcharova EP, Kattash M. Facial gunshot wounds: A 4-year experience. J Oral Maxillofac Surg 2001;59:277-82.

8. Becelli R, De Ponte FS, Sassano PP, Rinna C. Firearm injuries in maxillofacial region reconstructive surgery. J Craniofac Surg 1995;6:473-6.

9. Newlands SD, Samudrala S, Katzenmeyer K. Surgical treatment of gunshot injuries to the mandible. Otolaryngol Head Neck Surg 2003;129:239-44.

10. Motamedi MHK. Primary management of maxillofacial hard and soft tissue gunshot and shrapnel injuries. J Oral Maxillofac Surg 2003;61:1390-8. use a removable total prosthesis. This patient is awaiting nasal reconstruction, and an implant supported epithesis has been decided on that has still to be made.

\section{Discussion}

The demographic characteristics in our country basically follow two patterns: the first is made up of elderly patients from rural areas who, following a suicide attempt, have high energy injuries because of placing the weapon to the chin; the second pattern is made up of younger urban patients that suffer low energy injuries from lower caliber weapons that are produced following an aggression. These cases are increasing slowly in our cities. These patterns are not comparable with other studies that have been published due to the social and cultural differences in our country.

In our experience only one patient required urgent stabilization of the airways (16.6\%) coinciding with other series, due to the complexity of the facial injuries presented. 4,5 None of these cases had active bleeding as a result of injuries from the weapons, probably due to the thermal effect produced by the weapon on soft tissue, and there were no associated ocular or neurological injuries in the pattern of injuries suffered by our patients.

The treatment carried out for all these patients consisted in the stabilization of fractures and repair of the associated soft tissue by means of simple techniques. In this sense, we believe that it is the treatment of choice for most patients, and that complex microsurgery techniques should be left for a second stage once the defects and reconstruction needs of each patient have been properly outlined. Like other authors, we believe that secondary reconstruction should be carried out as swiftly as possible in order to achieve the best aesthetic and functional results. ${ }^{2,3}$

\section{Conclusions}

Firearm injuries are rare in our country and experience in this kind of treatment is limited. It is important that the initial management of these patients is comprehensive, as with any other polytraumatized patient, and definitive therapy of the injuries should be rationalized according to the characteristics of the patient and the experience of the team carrying out the treatment. 